\title{
PREPARATION OF W-Cu COMPOSITES BY INFILTRATION OF W SKELETONS - REVIEW
}

\author{
Jiří MATĚJÍČEK \\ Institute of Plasma Physics, Czech Academy of Sciences, Prague, Czech Republic, EU, \\ matejicek@ipp.cas.cz
}

https://doi.org/10.37904/metal.2021.4248

\begin{abstract}
Tungsten-copper composites feature high corrosion and erosion resistance, very good thermal and electrical conductivity, low thermal expansion and good mechanical properties. They are used in a variety of demanding applications, such as arc-resistant electrodes, high voltage electrical contacts, heat sinks for integrated circuits, etc. They are also foreseen for use in plasma-facing components of fusion reactors, e.g. as a transition layer between the (refractory) plasma-facing tungsten and the (highly conductive) copper-based cooling structure. In general, high density and good bonding of the tungsten and copper phases is desired. Molten copper infiltration into tungsten preforms is among the prospective fabrication technologies; the structure and properties of the resultant composites are dependent on the specific technological parameters.

In this paper, the preparation of W-Cu composites by infiltration of W skeletons is reviewed and attention is paid to the influence of these particular parameters: infiltration temperature, time and atmosphere, tungsten preform porosity, orientation and chemistry (presence or absence of other elements). Optimum parameter combinations for achieving high density and proper bonding of copper and tungsten are identified.
\end{abstract}

Keywords: Tungsten, copper, composites, molten copper infiltration

\section{INTRODUCTION}

Tungsten-copper composites combine a number of beneficial properties of both the constituents, such as the excellent thermal and electrical conductivity of copper and the high strength, hardness and erosion resistance and low thermal expansion of tungsten [1]. Thanks to these, they are used in a variety of demanding applications, such as arc-resistant electrodes, high voltage electrical contacts, heat sinks for integrated circuits, high-temperature erosion nozzles, etc. [1,2]. Moreover, W-Cu composites exhibit better machinability in comparison to pure tungsten [1]. These composites are also foreseen for use in plasma-facing components of fusion reactors, where a refractory and erosion-resistant material such as tungsten has to be provided on the plasma facing surface, while a highly conductive material such as copper is needed for the underlying heat sink. The largely different properties and operational temperature windows of these two materials present a major challenge, which can be alleviated by introducing an interlayer with intermediate properties, such as the composite [3]. This interlayer can also have a gradually varying composition, which further reduces the stress concentration $[4,5,6]$.

The W-Cu composites can be produced by a variety of techniques, including cold spraying [7], plasma spraying [8], high-velocity oxy-fuel spraying [9], selective laser melting [10] and various types of powder metallurgy techniques - for example, cold compaction + sintering [11], spark plasma sintering (SPS) [12], pulsed plasma sintering [13], microwave sintering [14], liquid phase sintering [15], hot pressing [16] or powder injection molding (PIM) [17]. A particular technique, making use of the largely different melting points of tungsten and copper, is the molten copper infiltration into pre-sintered tungsten skeletons, which is the focus of this paper. 
This technique results in a structure with both phases being contiguous, which can be beneficial for some applications. The contiguity of the phases may also affect the properties of the composite, such as thermal expansion [18] or thermal conductivity [19]. In general, high density of the composite and good bonding of the tungsten and copper phases is desired. This can be to a large extent influenced by the parameters of the fabrication technology. This paper reviews the prospective approaches in liquid copper infiltration into porous tungsten skeletons and focuses on specific parameters which affect the density and interparticle bonding.

\section{PREPARATION OF W-CU COMPOSITES BY LIQUID COPPER INFILTRATION}

This method generally consists of two steps: preparation of porous $\mathrm{W}$ skeleton by sintering and its infiltration by a molten copper. In the following, the role of these specific parameters will be discussed: infiltration temperature, infiltration time, infiltration atmosphere, W skeleton pore size, configuration of the infiltration setup and chemistry (of both the skeleton and the infiltrating liquid). An overview of parameters used in exemplary case studies in provided in Table 1.

\subsection{Infiltration temperature}

The melting point of copper is $1085{ }^{\circ} \mathrm{C}$. However, the experience shows that temperatures just above this value are generally not sufficient for a successful result. For proper filling of the porosity and good bonding of the copper and tungsten phases, proper wetting of the tungsten particles by the liquid copper is necessary. According to [20], the wetting angle is about $25^{\circ}$ at $1150{ }^{\circ} \mathrm{C}$, but it gets close to zero in the $1300-1400{ }^{\circ} \mathrm{C}$ range. Therefore, this temperature range can be considered optimal for proper wetting when infiltrating with pure copper and it has been used in majority of such experiments listed in Table 1. Using lower temperatures typically resulted in lower densities, although the differences were often moderate [20-22]. Still, in [3], infiltration at $1150^{\circ} \mathrm{C}$ is reported with apparently fully dense structure. Lower temperatures are generally used with alloys having lower melting point than pure copper, such as Cu-Zn alloy [23] or Cu-based metallic glasses [24, 25], or in combination with additional driving force for the infiltration, such as hot isostatic pressing (HIP) [26] or centrifugal force $[3,27]$. Besides the most common heating in a furnace, current heating (similar to spark plasma sintering) can be used; high current densities lead to markedly reduced processing times [30]. Combustion heating with the use of thermite reaction [29-31] can reach temperatures estimated in the $1800-$ $2500^{\circ} \mathrm{C}$ range.

\subsection{Infiltration time}

Typical processing times found in the literature (cf. Table 1) were in the range of 1-3 $\mathrm{h}$. The required time is necessitated to ensure thorough heating of both constituents, i.e. the skeleton and the infiltrant and to allow its full penetration throughout the structure. The latter factor depends also to some extent on the size of the final product. With the use of rapid heating techniques, the processing times can be significantly reduced e.g. for the combustion heating, times about 5 min were reported [29], for current-assisted melt infiltration (CAMI) even about $5 \mathrm{~s}$ [28]. The latter case resulted in ultra-fast processing, however, the produced composites were inhomogeneous and porous. When the liquid penetration was assisted by the centrifugal force, processing times of the order of 5 min were reported [27].

\subsection{Infiltration atmosphere}

The atmosphere under which the infiltration is carried out also plays a role. In the literature survey, either vacuum or inert gas (argon, nitrogen) were found, but most often a reducing atmosphere (hydrogen). Reducing atmosphere has the beneficial effect of suppressing the formation of tungsten oxides (or reducing those that may have been already present) [21]. Liquid copper has high contact angles with several oxides, therefore, oxidized $W$ skeleton is wetted less efficiently and this impedes the infiltration process. In [21], sintering and infiltration tests conducted in air were reported to result in no infiltration. Apart from vacuum, atmospheric 
pressure was used in practically all works surveyed; only in [26], a higher pressure argon (at $98 \mathrm{MPa}$ ) was used in a HIPping step (with the pre-form in an evacuated capsule) to aid the copper penetration. When gases are used, care must be taken to prevent their entrapment in the skeleton, which would hinder the infiltration and result in porosity in the finished product [21]. This can happen during spatially inhomogeneous advancement of the infiltrating copper that may enclose the gases remaining in the skeleton [21,32]. This will be further discussed in the subsequent section.

\subsection{Geometric configuration of the infiltration setup}

In general, two driving forces can operate during the copper infiltration - gravity and capillarity. Consequently, two variants of the mutual orientation of the copper and tungsten can be used in the most simple arrangements - when the copper is placed on top of the tungsten skeleton, it flows down freely into the pores under the action of gravity; when the skeleton is placed on top, the copper seeps into the pores driven by the capillary forces. In the literature surveyed, both instances were represented equally often (if mentioned at all). In [21], placing the skeleton on top is recommended, to prevent entrapment of the gases if the molten copper flows down faster on the sides of the preform than though the center. Gas entrapment can happen in the opposite configuration as well, as mentioned in [32]. Due to the wall tension, liquid copper may cover the lateral surfaces of the skeleton faster than penetrate through the bulk. To prevent this phenomenon, a zirconia coating on the bottom parts of the skeleton walls was used in [32]; the composites prepared with this uni-directional infiltration featured higher strength than those prepared without the zirconia layer.

In the more advanced configurations, such as combustion heating + centrifugal infiltration, the tungsten preform is placed at the extremity, in the direction of the centrifugal force, this is followed by the copper and termite (or their mixture) towards the center [29-31]. In [3,33] the centrifugal infiltration concept was used in a cylindrical geometry, when a tungsten preform consisting of braided fibers was placed in a rotating tube, with the copper infiltrating it from the center. This way, composites of tubular shapewere produced. In the CAMI method, Cu powder layer was sandwiched between two W powder layers [28]; because of different porosities, significantly higher current density was estimated for the W powder.

For larger compacts, some spatial variation of the infiltration process and therefore microstructure may occur. For example, in W-Cu compacts of $19 \mathrm{~mm}$ height, non-negligible variations in Cu content, W phase contiguity, hardness, elastic modulus and electric conductivity were observed [34].

\subsection{Porosity of the W skeleton}

To ensure a complete infiltration, the W skeleton needs to have a continuous network of open pores [4]. The size of the pores in the skeleton influences the infiltration process, as the capillary pressure is inversely proportional to the pore diameter [35]. The pore shape plays a role as well - deep and narrow pores take longer to infiltrate. For larger pores, the capillary pressure is smaller, thus they are easier to infiltrate; on the other hand, too large pores may be unable to retail the liquid, for the same reason. In [35], the following pore characteristics are recommended for optimum infiltration: sizes between 1 and $4 \mu \mathrm{m}$, length to radius ratio between 1 and 8 .

The pore size is primarily controlled by the size of the $\mathrm{W}$ feedstock forming the skeleton (typically powder) and the degree of its sintering. In the surveyed literature (cf. Table 1), the most typical W powder sizes were of the order of $\mu \mathrm{m}$, but the sizes used ranged from hundreds of $\mathrm{nm}$ to tens of $\mu \mathrm{m}$, without any obvious limitations for the degree of infiltration. For skeletons prepared from powders of narrow size distribution, the maximum achievable porosity is about $35 \%$ (the space among loosely packed powder particles); this can be only reduced by subsequent sintering. If a higher porosity volume - and therefore higher $\mathrm{Cu}$ content in the composite - is desired, additional steps need to be taken. In [4], the porosity of the W skeleton was increased by adding an amid wax as a placeholder, which was subsequently removed by debinding at moderate temperature before 
the final skeleton sintering. In [36], tungsten oxide was added to W powder to increase the W skeleton porosity; the oxide was reduced to tungsten by sintering in a hydrogen atmosphere. In [37], the porosity was increased by oxidation and volatilization of sintered $\mathrm{W}$ skeleton using a mixture of argon and water vapor at elevated temperature. All three approaches permit the formation of porosity gradients. Alternatively, a porosity gradient can be formed by layering of powders of varying size, as the degree of sintering generally increases with decreasing particle size $[26,32,37,38]$. The porosity can be further controlled by the feedstock geometry. For example, the usage of $\mathrm{W}$ preform consisting of braided $\mathrm{W}$ fibers resulted in much higher Cu content in the composite than in composites made from $\mathrm{W}$ powder [3]. The fiber-reinforced composites also featured higher strength than their powder-based counterparts $[39,40]$.

\subsection{Composition}

The outcome of the infiltration and thus the properties of the composite can be to a large extent influenced by the composition of both the preform and the infiltrant. Typically, the addition of certain (active) elements to the $W$ feedstock can a) improve the sintering of the skeleton itself, and b) increase the wetting of $W$ particles by the infiltrant, thereby improving the infiltration efficiency $[32,41]$. These elements are typically $\mathrm{Ni}, \mathrm{Co}, \mathrm{Fe}$ or $\mathrm{P}$ and can be applied either as a coating on the $\mathrm{W}$ particles or as a powder admixture; in the latter case, their action is facilitated by diffusion during the infiltration process.

Improved wetting by a small $\mathrm{Ni}$ additive was demonstrated in [32]. In a similar experiment, $\mathrm{Ni}$ was found to be better than $\mathrm{Co}$ [42]. In [43], 0.05\% addition of $\mathrm{Ni}$ was found optimal, while higher Ni content led to higher sintering temperature and lower homogeneity. In [44], W particles coated with $\mathrm{Ni}$, Ni-P and Cu-Ni-P have resulted in composites having higher density, but lower $\mathrm{W}$ contiguity. About $10 \%$ improvement of density of the infiltrated composite was found in [41] when using Ni or Ni-P coatings on the W powder, leading to reduced electric resistivity. In $[39,45]$, improved contiguity of Cr-coated W fibers and connectivity with neighboring W powder particles was demonstrated. Similar improvement was observed for Ni coating on the $\mathrm{W}$ fibers, leading to a marked improvement in tensile strength and electric breakdown strength of the composite [40].

Besides additional elements, the same material as the infiltrant, i.e. copper, can be also added to the $\mathrm{W}$ preform. In several studies, the preform was made from a mixture of $W$ and $\mathrm{Cu}$ [21,22,45-52]. This approach eases the sintering of the preform and also contributes to increased Cu content, however, can disturb the $\mathrm{W}$ contiguity. Application of $\mathrm{Cu}$ coating to the $\mathrm{W}$ powder has led to superior properties, such as homogeneity, hardness, electric and thermal conductivity and arc erosion resistance, compared to composites made from powder mixtures [48]. Additional reinforcement of the infiltrated $\mathrm{W}$-Cu composite by graphene results in improved uniformity and arc erosion resistance [53], while a Cu-coated graphene prevents interfacial reactions between tungsten and graphene and improves the structural homogeneity [54].

As mentioned before, replacement of copper with alloys having lower melting point permits using lower infiltration temperatures. For example, in [23], Cu80-Zn20 alloy was infiltrated at $1100^{\circ} \mathrm{C}$ into a W fiber preform with adequate density. For $\mathrm{Cu}$-based metallic glasses, infiltration temperatures in the $850-900{ }^{\circ} \mathrm{C}$ range were found optimal forCu $\mathrm{Cu}_{47} \mathrm{Ti}_{33} \mathrm{Zr}_{11} \mathrm{Ni}_{6} \mathrm{Sn}_{2} \mathrm{Si}_{1}$ [24] and around $965{ }^{\circ} \mathrm{C}$ for $\left(\mathrm{Cu}_{50} \mathrm{Zr}_{43} \mathrm{Al}_{7}\right)_{99.5} \mathrm{Si}_{0.5}$ [25].

\section{CONCLUSION}

In this article, the preparation of W-Cu composites by liquid $\mathrm{Cu}$ infiltration of $\mathrm{W}$ skeletons was reviewed. The role if specific technological parameters, namely the infiltration temperature, time and atmosphere, geometric arrangement, skeleton porosity and composition of the preform and infiltrant, was addressed. From a number of surveyed case studies, the suitable parameter combinations for achieving high density and good bonding of the $\mathrm{W}$ and $\mathrm{Cu}$ phases were pinpointed. These results can aid in the preparation of such composites for demanding applications or in further developments of the technique. 
Table 1 Overview of technological parameters used in the surveyed case studies on Cu-infiltration of W skeletons. Ref. $=$ reference, Preform $=$ characteristics of the preform, $\mathrm{Cu}$ infiltration - parameters of the infiltration, Atm. = atmosphere used during the infiltration, Main advantage - factor(s) of a particular setup that are considered advantageous

\begin{tabular}{|c|c|c|c|c|}
\hline Ref. & Preform & Cu infiltration & Atm. & Main advantage \\
\hline$[32]$ & $\begin{array}{c}\text { W } 6 \mu \mathrm{m} \text {, sintered at } 1400-2150 \\
{ }^{\circ} \mathrm{C}, \mathrm{H} 2, \sim 78 \% \text { density } \\
\text { W+0.05\%Ni milled } \\
\text { +ZrO2 wall to reduce wall tension }\end{array}$ & $1300{ }^{\circ} \mathrm{C}, 2 \mathrm{~h}$ & $\mathrm{H}_{2}$ & $\begin{array}{l}\text { 1) } \mathrm{Ni} \text { additive - improved } \\
\text { wetting } \\
\text { 2) } \mathrm{ZrO}_{2} \text { wall -> directional } \\
\text { infiltration, no trapped gas }\end{array}$ \\
\hline$[42]$ & $\begin{array}{c}W 6 \mu \mathrm{m}+0.05,0.25,0.5 \% \mathrm{Ni} \text { or } \\
\text { Co }\end{array}$ & $1250-1300{ }^{\circ} \mathrm{C}, 2 \mathrm{~h}$ & $\mathrm{H}_{2}$ & $\begin{array}{l}\text { additives for improved } \\
\text { wetting }\end{array}$ \\
\hline$[44]$ & $\begin{array}{l}\text { W } 8 \mu \mathrm{m} \text {, electroless-plated by Ni, } \\
\text { Ni-P, Ni-Cu-P }\end{array}$ & $1300{ }^{\circ} \mathrm{C}$ & $\mathrm{H}_{2}$ & coating for better wetting \\
\hline$[28]$ & W $100 \mathrm{~nm}, \mathrm{Cu} 45 \mu \mathrm{m}$ & $\begin{array}{l}\text { current-activated melt } \\
\text { infiltration }\end{array}$ & $\operatorname{Ar}$ & rapid heating \\
\hline$[35]$ & $\begin{array}{c}W \sim 10 \mu \mathrm{m}, \text { sintered at } 1330{ }^{\circ} \mathrm{C} / 5 \mathrm{~h} \\
+1790^{\circ} \mathrm{C} / 5 \mathrm{~h}, \mathrm{H} 2\end{array}$ & $1400^{\circ} \mathrm{C}$, graphite boat, $2 \mathrm{~h}$ & $\mathrm{H}_{2}$ & \\
\hline$[20]$ & W fiber preforms & $\begin{array}{c}1200,1300^{\circ} \mathrm{C}, 1 \mathrm{~h} \text {, alumina } \\
\text { crucible }\end{array}$ & & \\
\hline$[43]$ & $\begin{array}{c}\mathrm{W}<6 \mu \mathrm{m}+0.05,0.25,0.5 \% \mathrm{Ni} \\
\text { sintered at } 1250-1550^{\circ} \mathrm{C}, 4 \mathrm{~h}, \mathrm{H} 2\end{array}$ & $1300{ }^{\circ} \mathrm{C}, 1 \mathrm{~h}$ & $\mathrm{H} 2$ & $\begin{array}{l}\mathrm{Ni} \text { additive for improved } \\
\text { wetting }\end{array}$ \\
\hline$[55]$ & $\begin{array}{c}W<6 \mu \mathrm{m}, \text { sintered at } 1550^{\circ} \mathrm{C}, 4 \mathrm{~h}, \\
\mathrm{H} 2, \mathrm{p}=200-663 \mathrm{MPa}\end{array}$ & $1300{ }^{\circ} \mathrm{C}, 1 \mathrm{~h}$ & $\mathrm{H} 2$ & $\begin{array}{c}\text { higher } \mathrm{p}->\text { lower } \mathrm{T} \text { for } \mathrm{W} \\
\text { sintering }\end{array}$ \\
\hline$[30,31]$ & $\begin{array}{c}\text { W fibers }+ \text { Cu powder preform }+ \\
\text { thermite }\end{array}$ & $\begin{array}{l}\text { Combustion synthesis melt } \\
\text { infiltration under ultra-high } \\
\text { gravity, } \sim 2550^{\circ} \mathrm{C}\end{array}$ & $\begin{array}{l}\text { vacuum } \\
100 \mathrm{~Pa}\end{array}$ & centrifugal force + high $T$ \\
\hline$[46]$ & $\begin{array}{c}\mathrm{W} 1.3 \mu \mathrm{m}+\mathrm{Cu} 1 \mu \mathrm{m} ; \text { sintered at } \\
1000^{\circ} \mathrm{C}, 2 \mathrm{~h}\end{array}$ & $1300{ }^{\circ} \mathrm{C}, 3 \mathrm{~h}$ & $\mathrm{H}_{2}$ & \\
\hline$[21]$ & W $1 \mu \mathrm{m}, \mathrm{Cu} 10 \mu \mathrm{m}$ PIM preforms & $1150,1200,1250^{\circ} \mathrm{C}, 1 \mathrm{~h}$ & $\mathrm{H}_{2}$ & \\
\hline [23] & W fibers & $1100^{\circ} \mathrm{C}, 4 \mathrm{~h}$ (Cu-Zn alloy) & $\mathrm{H}_{2}$ & \\
\hline [47] & $\begin{array}{c}\text { W 5-7 } \mu \mathrm{m}, \mathrm{Cu}<80 \mu \mathrm{m} ; 80: 20 \text { and } \\
70: 30\end{array}$ & $1350^{\circ} \mathrm{C}, 90 \mathrm{~min}$ & $\mathrm{H}_{2}$ & $\begin{array}{l}\text { cold pressing of powder } \\
\text { mixture }+ \text { infiltration } \\
\text { sintering }\end{array}$ \\
\hline [48] & $\begin{array}{c}\text { W 6-8 } \mu \mathrm{m}+\text { Cu mixture; Cu- } \\
\text { coated W 12-14 } \mu \mathrm{m}\end{array}$ & $1350^{\circ} \mathrm{C}, 90 \mathrm{~min}$ & $\mathrm{H}_{2}$ & $\begin{array}{l}\text { cold pressing of powder }+ \\
\text { infiltration sintering }\end{array}$ \\
\hline$[26]$ & $\begin{array}{c}\text { graded W }(1-3 \mu \mathrm{m}) \text { skeleton, } \\
\text { sintered at } 1770{ }^{\circ} \mathrm{C}, 0.1 \mathrm{MPa}, \mathrm{Ar}, \\
8 \mathrm{~h} \text {, open HIPped at } 1800^{\circ} \mathrm{C}, 181 \\
\mathrm{MPa}, \mathrm{Ar}, 4 \mathrm{~h}\end{array}$ & $1100{ }^{\circ} \mathrm{C}, 2 \mathrm{~h}$ & $\operatorname{Ar}$ & $\begin{array}{l}\text { evacuated HIP can, } \mathrm{Ar} \\
\text { pressure } 98 \mathrm{MPa}\end{array}$ \\
\hline$[24]$ & W wires $800 \mu \mathrm{m}$ & $\begin{array}{c}800-1000{ }^{\circ} \mathrm{C}, 10-30 \mathrm{~min}(\mathrm{Cu}- \\
\text { based metallic glass) }\end{array}$ & $\mathrm{Ar}$ & \\
\hline$[39]$ & $\begin{array}{l}\text { W wires, coated by } \mathrm{Cr} \text { by PVD + } \\
\text { W+Cu+Ni powder; pre-sintered }\end{array}$ & $1300{ }^{\circ} \mathrm{C}, 2 \mathrm{~h}$ & $\mathrm{H}_{2}$ & Cr coating \\
\hline$[22]$ & $\begin{array}{c}\mathrm{W} 4 \mu \mathrm{m}+24 \% \mathrm{Cu}<63 \mu \mathrm{m}+1 \% \mathrm{Ni} \\
5 \mu \mathrm{m}, \text { pressed and sintered at } 950 \\
{ }^{\circ} \mathrm{C}, 30 \mathrm{~min}\end{array}$ & $1150{ }^{\circ} \mathrm{C}, 30 \mathrm{~min}$ & $\mathrm{H}_{2}, \mathrm{~N}_{2}$ & \\
\hline
\end{tabular}




\begin{tabular}{|c|c|c|c|c|}
\hline [37] & $\begin{array}{c}\text { W skeletons with porosity } \\
\text { gradient prepared by oxidation } \\
\text { and volatilization }\end{array}$ & no details & & porosity gradient \\
\hline$[41]$ & $\begin{array}{c}\text { W } 8 \mu \mathrm{m} \text {, electroless-plated by } \mathrm{Ni} \text {, } \\
\mathrm{Ni}-\mathrm{P}, \text { pressed at } 348 \mathrm{MPa}\end{array}$ & $1300^{\circ} \mathrm{C}, 1 \mathrm{~h}$ & $\begin{array}{l}\mathrm{N}_{2} / \mathrm{H}_{2} \\
80 / 20\end{array}$ & coating for better wetting \\
\hline [3] & $\begin{array}{l}\text { W skeleton, cold pressed + } \\
\text { sintered at } 1150^{\circ} \mathrm{C}, 2 \mathrm{~h}, \mathrm{H}_{2}\end{array}$ & $1150^{\circ} \mathrm{C}, 2 \mathrm{~h}$ & $\mathrm{H}_{2}$ & \\
\hline$[3,33]$ & braided $W$ fibers, $50 \mathrm{~mm}$ & centrifugal melt infiltration & & $\begin{array}{l}\text { centrifugal melt infiltration } \\
\text { for tubular shape } \\
\text { composite }\end{array}$ \\
\hline$[25]$ & W wires & $\begin{array}{c}965,990,1015^{\circ} \mathrm{C}, 10,15 \\
\min (\mathrm{Cu}-\text { based metallic } \\
\text { glass) }\end{array}$ & & \\
\hline$[36]$ & $\begin{array}{l}\text { W powder } 2 \mu \mathrm{m}+5 \%, 10 \%, 15 \% \\
\text { BTO powder } 11 \mu \mathrm{m}, \text { cold pressed } \\
\quad+\text { sintered at } 1400^{\circ} \mathrm{C}, \mathrm{H}_{2}\end{array}$ & $1300^{\circ} \mathrm{C}, 1 \mathrm{~h}$ & $\mathrm{H}_{2}$ & $\begin{array}{l}\text { blue tungsten oxide (BTO) } \\
\text { addition to increase W } \\
\text { skeleton porosity }\end{array}$ \\
\hline [49] & $\begin{array}{c}\mathrm{W} 10 \mu \mathrm{m}+5 \%, 8 \%, 20 \% \text { Cu } 22 \mu \mathrm{m} \\
\text { mixture, pressed }\end{array}$ & $\begin{array}{c}\text { microwave vacuum } \\
\text { infiltration sintering, } 1200 \\
{ }^{\circ} \mathrm{C}, 3 \mathrm{~h}\end{array}$ & vacuum & \\
\hline [4] & $\begin{array}{c}\text { W } 4 \mu \mathrm{m}+\text { amid wax, pressed + } \\
\text { sintered at } 1200^{\circ} \mathrm{C}, 1 \mathrm{~h}, \mathrm{H}_{2}\end{array}$ & $\begin{array}{l}1200{ }^{\circ} \mathrm{C}, 30 \mathrm{~min}(\mathrm{Cu} 1 \mathrm{CrZr} \\
\text { alloy); Cu1CrZr plate on top }\end{array}$ & & $\begin{array}{l}\text { additive for porosity } \\
\text { control }\end{array}$ \\
\hline$[50]$ & $\begin{array}{c}\mathrm{W} 8 \mu \mathrm{m}, 800,600,400 \mathrm{~nm}+\mathrm{Cu} \\
50 \mu \mathrm{m}, 75: 25, \text { pressed at } 340 \mathrm{MPa}\end{array}$ & $\begin{array}{l}\text { sintering+infiltration } 1350 \\
{ }^{\circ} \mathrm{C}, 40 \mathrm{~min}\end{array}$ & $\mathrm{H}_{2}$ & $\begin{array}{l}\text { fine } W \text { powders -> bi- } \\
\text { continuous structure }\end{array}$ \\
\hline [27] & $\begin{array}{c}\text { W 1-6 } \mu \mathrm{m}, \text { pressed, sintered at } \\
1350{ }^{\circ} \mathrm{C}, 1.5 \mathrm{~h}, \mathrm{H}_{2}\end{array}$ & $\begin{array}{l}\text { centrifugal infiltration, } 1150 \\
{ }^{\circ} \mathrm{C}, 5 \mathrm{~min}\end{array}$ & $\begin{array}{l}\text { vacuum } \\
\text { or added } \\
\text { flux }\end{array}$ & \\
\hline$[51]$ & $\begin{array}{l}\text { W } 500 \mathrm{~nm}+\mathrm{Cu} 50-70 \mu \mathrm{m}, 75: 25 \text {, } \\
\text { pressed + sintered at 1050, 1150, } \\
\qquad 1250,1350^{\circ} \mathrm{C}, 2 \mathrm{~h}, \mathrm{H}_{2}\end{array}$ & $2 \mathrm{~h}$ & $\mathrm{H}_{2}$ & \\
\hline [29] & $\begin{array}{c}\mathrm{W} 3 \mu \mathrm{m}+\mathrm{Cu} 3 \mu \mathrm{m} \text { blends }+ \\
\text { thermite }\end{array}$ & $\begin{array}{l}\text { high-gravity combustion } \\
\text { synthesis and melt- } \\
\text { infiltration, } \mathrm{T}^{\sim} 1800^{\circ} \mathrm{C}, 5 \mathrm{~min}\end{array}$ & & centrifugal force + high $\mathrm{T}$ \\
\hline$[54]$ & $\begin{array}{l}\text { W 5-7 } \mu \mathrm{m}+\mathrm{Cu} 3-5 \mu \mathrm{m}+\mathrm{Cu}- \\
\text { coated graphene, pressed }\end{array}$ & $\begin{array}{c}\text { Cu block on top, } 1300{ }^{\circ} \mathrm{C}, 90 \\
\min \end{array}$ & $\mathrm{Ar}$ & \\
\hline$[40]$ & $\begin{array}{l}\text { W powder } 4-6 \mu \mathrm{m}+\mathrm{Cu} \text { powder } \\
50-70 \mu \mathrm{m}+\mathrm{W} \text { fibers (uncoated or } \\
\text { Ni-coated by electrolessplating), } \\
\text { pressed }+ \text { sintered at } 1300^{\circ} \mathrm{C}, 2 \mathrm{~h}\end{array}$ & $1300^{\circ} \mathrm{C}, 2 \mathrm{~h}$ & $\mathrm{H}_{2}$ & $\begin{array}{l}\text { Ni coating for reduced } \\
\text { porosity }\end{array}$ \\
\hline$[45]$ & $\begin{array}{l}\text { W powder } 500 \mathrm{~nm}+\mathrm{Cu} \text { powder } \\
50-70 \mu \mathrm{m}+\mathrm{W} \text { fibers }(\mathrm{Cr} \text {-coated } \\
\text { by magnetron sputtering), } \\
\text { pressed }+ \text { sintered at } 1350^{\circ} \mathrm{C}, 2 \mathrm{~h}\end{array}$ & $1350^{\circ} \mathrm{C}, 2 \mathrm{~h}$ & $\mathrm{H}_{2}$ & $\begin{array}{l}\text { Cr coating for improved } \\
\text { sintering }\end{array}$ \\
\hline [52] & $\begin{array}{l}\text { W powder } 4-6 \mu \mathrm{m}+\mathrm{Cu} \text { powder } \\
50-70 \mu \mathrm{m}+\mathrm{W} \text { fibers (Ti-coated by } \\
\text { magnetron sputtering), pressed }+ \\
\text { sintered at } 1350^{\circ} \mathrm{C}, 2 \mathrm{~h}\end{array}$ & $1300^{\circ} \mathrm{C}, 2 \mathrm{~h}(\mathrm{Cu}+0.5 \% \mathrm{Cr})$ & $\mathrm{H}_{2}$ & $\begin{array}{l}\text { Ti coating for improved } \\
\text { sintering }\end{array}$ \\
\hline [34] & $\begin{array}{l}\text { W powder, pressed at } 300 \mathrm{MPa} \text {, } \\
\text { sintered at } 1550^{\circ} \mathrm{C}, 4 \mathrm{~h}, \mathrm{H}_{2}\end{array}$ & $1300^{\circ} \mathrm{C}, 1 \mathrm{~h}, \mathrm{Cu}$ on top & $\mathrm{H}_{2}$ & $\begin{array}{l}\text { study of spatial } \\
\text { homogeneity }\end{array}$ \\
\hline
\end{tabular}




\section{ACKNOWLEDGEMENTS}

\section{This work was supported by Technology Agency of the Czech Republic through grant no. TK03030045.}

\section{REFERENCES}

[1] DONG, L.L., AHANGARKANI, M., CHEN, W.G., ZHANG, Y.S. Recent progress in development of tungstencopper composites: Fabrication, modification and applications. International Journal of Refractory Metals and Hard Materials. 2018, vol. 75, pp. 30-42.

[2] ABU-OQAIL, A., GHANIM, M., EL-SHEIKH, M., EL-NIKHAILY, A. Effects of processing parameters of tungstencopper composites. Int. J. Refract. Met. Hard Mater. 2012, vol. 35, pp. 207-212.

[3] MULLER, A. V. et al. Melt infiltrated tungsten-copper composites as advanced heat sink materials for plasma facing components of future nuclear fusion devices. Fusion Eng. Des. 2017, vol. 124, pp. 455-459.

[4] YOU, J. H., BRENDEL, A., NAWKA, S., SCHUBERT, T., KIEBACK, B. Thermal and mechanical properties of infiltrated W/CuCrZr composite materials for functionally graded heat sink application. J. Nucl. Mater. 2013, vol. 438, pp. 1-6.

[5] AUTISSIER, E., RICHOU, M., MINIER, L., GARDAREIN, J. L., BERNARD, F. Elaboration and thermomechanical characterization of W/Cu functionally graded materials produced by Spark Plasma Sintering for plasma facing components. Fusion Eng. Des. 2015, vol. 98-99, pp. 1929-1932.

[6] RICHOU, M.et al. Performance assessment of thick W/Cu graded interlayer for DEMO divertor target. Fusion Eng. Des. 2020, vol. 157, paper no. 111610.

[7] PETROVSKIY, P., DOUBENSKAIA, M., SOVA, A., TRAVYANOV, A. Analysis of copper-tungsten cold spray coating: Kinetics of coating formation and its thermal properties. Surf. Coatings Technol. 2020, vol. 385, paper no. 125376.

[8] MATĚJÍČEK, J.et al. The role of spraying parameters and inert gas shrouding in hybrid water-argon plasma spraying of tungsten and copper for nuclear fusion applications. Journal of Thermal Spray Technology. 2013, vol. 22, pp. 744-755.

[9] MATĚJíČEK, J., ZAHÁLKA, F., BENSCH, J., CHI, W., SEDLÁČEK, J. Copper-tungsten composites sprayed by HVOF. J. Therm. Spray Technol. 2008, vol. 17, pp. 177-180.

[10] TAN, C., ZHOU, K., KUANG, T. Selective laser melting of tungsten-copper functionally graded material. Mater. Lett. 2019, vol. 237, pp. 328-331.

[11] IBRAHIM, A., ABDALLAH, M., MOSTAFA, S. F., HEGAZY, A. A. An experimental investigation on the W-Cu composites. Mater. Des. 2009, vol. 30, pp. 1398-1403.

[12] PERVIKOV, A. V.et al. Synthesis of W-Cu composite nanoparticles by the electrical explosion of two wires and their consolidation by spark plasma sintering. Mater. Res. Express. 2019, vol. 6, paper no. $1265 i 9$.

[13] ROSINSKI, M., FORTUNA, E., MICHALSKI, A., PAKIELA, Z., KURZYDLOWSKI, K. J. W/Cu composites produced by pulse plasma sintering technique (PPS). Fusion Eng. Des. 2007, vol. 82, pp. 2621-2626.

[14] MONDAL, A., AGRAWAL, D., UPADHYAYA, A. Microwave sintering of refractory metals/alloys: W, Mo, Re, W$\mathrm{Cu}, \mathrm{W}-\mathrm{Ni}-\mathrm{Cu}$ and W-Ni-Fe alloys. Journal of Microwave Power and Electromagnetic Energy. 2010, vol. 44, pp. 2844.

[15] LI, D., LIU, Z., YU, Y., WANG, E. Research on the densification of W-40 wt.\% Cu by liquid sintering and hothydrostatic extrusion. Int. J. Refract. Met. Hard Mater. 2008, vol. 26, pp. 286-289.

[16] ROOSTA, M., BAHARVANDI, H. The comparison of W/Cu and W/ZrC composites fabricated through hot-press. Int. J. Refract. Met. Hard Mater. 2010, vol. 28, pp. 587-592.

[17] CHENG, J.et al. Fabrication of W-20 wt.\% Cu alloys by powder injection molding. J. Mater. Process. Technol. 2010, vol. 210, pp.137-142.

[18] ROUDINI, G., TAVANGAR, R., WEBER, L., MORTENSEN, A. Influence of reinforcement contiguity on the thermal expansion of alumina particle reinforced aluminium composites. Int. J. Mater. Res. 2010, vol. 101, pp. 1113-1120. 
[19] JOHNSON, J. L., PARK, S. J., KWON, Y. S., GERMAN, R. M. The effects of composition and microstructure on the thermal conductivity of liquid-phase-sintered W-Cu. Metall. Mater. Trans. A. 2010, vol. 41A, pp. 1565-1572.

[20] DUAN, L., LIN, W., WANG, J., YANG, G. Thermal properties of W-Cu composites manufactured by copper infiltration into tungsten fiber matrix. Int. J. Refract. Met. Hard Mater. 2014, vol. 46, pp. 96-100.

[21] HO, P. W., LI, Q. F., FUH, J. Y. H. Evaluation of W-Cu metal matrix composites produced by powder injection molding and liquid infiltration. Mater. Sci. Eng. A. 2008, vol. 485, pp. 657-663.

[22] LUNGU, M. V.et al. Development and Investigation of Tungsten Copper Sintered Parts for Using in Medium and High Voltage Switching Devices. IOP Conference Series: Materials Science and Engineering Institute of Physics Publishing. 2017, vol. 209, paper no. 012012.

[23] $\mathrm{HU}, \mathrm{Z}$. et al. Preparation and anisotropic compressive deformation behaviors of tungsten fiber reinforced $\mathrm{Cu}-\mathrm{Zn}$ matrix composite. Mater. Sci. Eng. A. 2017, vol. 708, pp. 43-49.

[24] KHADEMIAN, N., GHOLAMIPOUR, R. Effects of infiltration parameters on mechanical and microstructural properties of tungsten wire reinforced Cu47Ti33Zr 11Ni6Sn2Si1 metallic glass matrix composites. Trans. Nonferrous Met. Soc. China English Ed. 2013, vol. 23, pp. 1314-1321.

[25] SAEIDABADI, E. K., GHOLAMIPOUR, R., GHASEMI, B. Effect of melt infiltration parameters on microstructure and mechanical properties of tungsten wire reinforced (Cu50Zr43Al799.5)Si0.5 metallic glass matrix composite. Trans. Nonferrous Met. Soc. China English Ed. 2015, vol. 25, pp. 2624-2629.

[26] ITOH, Y., TAKAHASHI, M., TAKANO, H. Design of tungsten/copper graded composite for high heat flux components. Fusion Eng. Des. 1996, vol. 31, pp. 279-289.

[27] ZHANG, N., WANG, Z., GUO, L., MENG, L., GUO, Z. Rapid fabrication of W-Cu composites via low-temperature infiltration in supergravity fields. J. Alloys Compd. 2019, vol. 809,.

[28] DAOUSH, W. M., YAO, J., SHAMMA, M., MORSI, K. Ultra-rapid processing of high-hardness tungsten-copper nanocomposites. Scr. Mater. 2016, vol. 113, pp. 246-249.

[29] ZHAO, P., GUO, S. B., LIU, G. H., CHEN, Y. X., LI, J. T. Fast fabrication of W-Cu functionally graded material by high-gravity combustion synthesis and melt-infiltration. J. Nucl. Mater. 2014, vol. 445, pp. $26-29$.

[30] HE, G.et al. Preparation of tungsten fiber reinforced-tungsten/copper composite for plasma facing component. J. Nucl. Mater. 2014, vol. 455, pp. 225-228.

[31] GUO, S., HE, G., LIU, G., YANG, Z., LI, J. Interfacial failure mechanism in tungsten fiber reinforced copper-based composites fabricated by combustion synthesis melt infiltration under ultra-high gravity. Mater. Des. 2015, vol. 87, pp. 901-904.

[32] AHANGARKANI, M., ZANGENEH-MADAR, K., BORJI, S. Microstructural study on the effect of directional infiltration and $\mathrm{Ni}$ activator on tensile strength and conductivity of W-10 wt\% Cu composite. Int. J. Refract. Met. Hard Mater. 2018, vol. 71, pp. 340-351.

[33] MÜLLER, A. V.et al. Application of tungsten-copper composite heat sink materials to plasma-facing component mock-ups. Physica Scripta. 2020, vol. T171, paper no. 014015.

[34] PAIDPILLI, M., UPADHYAYA, A., MISHRA, D. K., KHANRA, G. P., SHARMA, S. C. Investigation of sintered properties on infiltrated tungsten-copper composite along the infiltration direction. Can. Metall. Q. 2018, vol. 57, pp. 120-128.

[35] DAS, J., CHAKRABORTY, A., BAGCHI, T. P., SARMA, B. Improvement of machinability of tungsten by copper infiltration technique. Int. J. Refract. Met. Hard Mater. 2008, vol. 26, pp. 530-539.

[36] WANG, C. P.et al. Effect of blue tungsten oxide on skeleton sintering and infiltration of W-Cu composites. Int. J. Refract. Met. Hard Mater. 2013, vol. 41, pp. 236-240.

[37] MA, X. X., XIAO, B., CAO, S. H., CHEN, B. H., XU, H. A novel approach to fabricate W/Cu functionally gradient materials. Int. J. Refract. Met. Hard Mater. 2018, vol. 72, pp. 183-193.

[38] NEVRLÁ, B., VILÉMOVÁ, M., MATĚJÍČEK, J. Thermal and mechanical properties of tungsten compacts prepared by SPS. In: Proceedings of XIIIth youth symposium on experimental solid mechanics. Prague: Czech Technical University in Prague, 2014, pp. 80-83.

[39] LIANG, S.et al. Infiltrated W-Cu composites with combined architecture of hierarchical particulate tungsten and tungsten fibers. Mater. Charact. 2015, vol. 110, pp. 33-38. 
[40] ZHUO, L.et al. Fabrication and properties of the W-Cu composites reinforced with uncoated and nickel-coated tungsten fibers. Int. J. Refract. Met. Hard Mater. 2018, vol. 71, pp. 175-180.

[41] ZANGENEH-MADAR, K., AMIRJAN, M., PARVIN, N. Improvement of physical properties of Cu-infiltrated W compacts via electroless nickel plating of primary tungsten powder. Surf. Coatings Technol. 2009, vol. 203, pp. 2333-2336.

[42] AHANGARKANI, M., ZANGENEH-MADAR, K. Investigation on the microstructure and properties of W-10 wt\% Cu prepared by sintering and infiltration. Int. J. Refract. Met. Hard Mater. 2018, vol. 75, pp. 1-9.

[43] GHADERI HAMIDI, A., ARABI, H., RASTEGARI, S. Tungsten-copper composite production by activated sintering and infiltration. Int. J. Refract. Met. Hard Mater.2011, vol. 29, pp. 538-541.

[44] AMIRJAN, M., ZANGENEH-MADAR, K., PARVIN, N. Evaluation of microstructure and contiguity of W/Cu composites prepared by coated tungsten powders. Int. J. Refract. Met. Hard Mater. 2009, vol. 27, pp. 729-733.

[45] ZHUO, L.et al. Preparation and properties of ultrafine-grained W-Cu composites reinforced with tungsten fibers. Mater. Lett. 2019, vol. 243, pp. 26-29.

[46] GUO, W., WANG, Y., LIU, K., LI, S., ZHANG, H. Effect of copper content on the dynamic compressive properties of fine-grained tungsten copper alloys. Mater. Sci. Eng. A. 2018, vol. 727, pp. 140-147.

[47] HUANG, Y., ZHOU, X., HUA, N., QUE, W., CHEN, W. High temperature friction and wear behavior of tungsten copper alloys. Int. J. Refract. Met. Hard Mater. 2018, vol. 77, pp. 105-112.

[48] CHEN, W.et al. Infiltration sintering of WCu alloys from copper-coated tungsten composite powders for superior mechanical properties and arc-ablation resistance. J. Alloys Compd. 2017, vol. 728, pp. 196-205.

[49] XU, L.et al. Influence of copper content on the property of Cu-W alloy prepared by microwave vacuum infiltration sintering. J. Alloys Compd. 2014, vol. 592, pp. 202-206.

[50] ZHANG, Q., LIANG, S., HOU, B., ZHUO, L. The effect of submicron-sized initial tungsten powders on microstructure and properties of infiltrated W-25 wt.\% Cu alloys. Int. J. Refract. Met. Hard Mater. 2016, vol. 59, pp. 87-92.

[51] ZHANG, Y.et al. The influence of pre-sintering temperature on the microstructure and properties of infiltrated ultrafine-grained tungsten-copper composites. J. Alloys Compd. 2020, vol. 823, paper no. 153761.

[52] ZHUO, L. et al. Infiltrated tungsten-copper composite reinforced with short tungsten fibers. Vacuum. 2020, vol. 173, paper no. 109123

[53] DONG, L., CHEN, W., DENG, N., SONG, J., WANG, J. Investigation on arc erosion behaviors and mechanism of W70Cu30 electrical contact materials adding graphene. J. Alloys Compd. 2017, vol. 696, pp. 923-930

[54] ZHOU, K., CHEN, W. G., WANG, J. J., YAN, G. J., FU, Y. Q. W-Cu composites reinforced by copper coated graphene prepared using infiltration sintering and spark plasma sintering: A comparative study. Int. J. Refract. Met. Hard Mater. 2019, vol. 82, pp. 91-99.

[55] GHADERI HAMIDI, A., ARABI, H., RASTEGARI, S. A feasibility study of W-Cu composites production by high pressure compression of tungsten powder. Int. J. Refract. Met. Hard Mater. 2011, vol. 29, pp. 123-127. 